\title{
PERAN BIAYA OPERASIONAL PENDIDIKAN TERHADAP OUTPUT PENDIDIKAN
}

\author{
Muhammad Imad* \& Hamdan Herdiawan** \\ UIN Sunan Gunung Djati Bandung \\ *moch.imad7@gmail.com \\ **imad_muhammad@yahoo.co.id
}

\begin{abstract}
Operational Education Costs are one of the most important instrumental input components in the administration of education. The education process cannot run without the support of operational costs. Madrasah Aliyah is a formal education unit under the auspices of the Ministry of Religion which organizes general education with the distinctiveness of the Islamic religion at the secondary education level. Educational activities carried out by schools including Madrasah Aliyah must be based on the educational goals to be achieved. One of the achievement of educational goals can be seen from the results of learning or educational output. Parents of students dare to pay bigh education costs not to obtain low educational output, but they want high educational output. The purpose of this study was to determine the role of the operational costs of education on educational output in Madrasab Aliyah in Cimahi. This research uses descriptive study method, because the problem under study is an actual and factual so that the researcher is able to study intensively about the background of the present situation. In this study the authors used several data collection techniques, namely observation, interviews and documentation studies. In this study there are 2 Aliyah Madrasas which are used as sample objects for comparison so that researchers know the role of educational operational costs to educational output, namely Madrasah Aliyah Mutiteknik Asih Putera and Madrasah Aliyah Al-Farisy. While the educational output in this study is seen from the average value of NEM for the National Examination of students from each school. From various data obtained by the author about the object of research, the results of the study indicate that the role of operational operational costs in this research has an influence on educational output. This means that high operational costs of education on average result in better educational outputs.
\end{abstract}

Keywords: Educational Operational Costs, Madrasah Aliyah, Education Output

\begin{abstract}
Abstrak : Biaya Operasional Pendidikan merupakan salah satu komponen masukan instrumental yang sangat penting dalam penyelenggaraan pendidikan. Proses pendidikan tidak dapat berjalan tanpa dukungan biaya operasional. Madrasah Aliyah merupakan satuan pendidikan formal dalam binaan Kementrian Agama yang menyelenggarakan pendidikan umum dengan kekhasan agama islam pada jenjang pendidikan menengah. Kegiatan pendidikan yang dijalankan oleh sekolah termasuk juga Madrasah Aliyah harus berdasarkan
\end{abstract}

Manazhim : Jurnal Manajemen dan Ilmu Pendidikan

Volume 1, Nomor 2, Agustus 2019; 152-165

https://ejournal.stitpn.ac.id/index.php/manazhim 
pada tujuan pendidikan yang ingin dicapai. Pencapaian tujuan pendidikan salah satunya dapat dilihat dari hasil belajar atau output pendidikan. Orang tua siswa berani mengeluarkan biaya pendidikan yang tinggi bukan untuk memperoleh output pendidikan yang rendah, akan tetapi mereka menginginkan output pendidikan yang tinggi. Tujuan penelitian ini adalah untuk mengetahui peran biaya operasional pendidikan terhadap output pendidikan di Madrasah Aliyah yang berada di kota Cimahi. Penelitian ini menggunakan metode studi deskriptif, karena permasalahan yang diteliti merupakan suatu yang aktual dan faktual sehingga peneliti mampu mempelajari secara intensif tentang latar belakang keadaan sekarang. Dalam penelitian ini penulis menggunakan beberapa teknik pengumpulan data yaitu observasi ,wawancara dan studi dokumentasi. Pada penelitian ini ada 2 Madrasah Aliyah yang menjadi objek sampel untuk dijadikan perbandingan sehingga peneliti mengetahui peran biaya operasional pendidikan terhadap output pendidikan yakni Madrasah Aliyah Mutiteknik Asih Putera dan Madrasah Aliyah Al-Farisy. Sedangkan output pendidikan pada penelitian ini dilihat dari nilai rata-rata NEM Ujian Negara siswa dari setiap sekolahnya. Dari berbagai data yang diperoleh penulis tentang objek penelitian, maka hasil penelitian menunjukkan bahwa peran biaya operasional pendidikan pada peneltian ini memberikan pengaruh terhadap output pendidikan. Artinya biaya operasional pendidikan yang tinggi rata-rata mengakibatkan hasil output pendidikan yang lebih baik.

Kata Kunci: Biaya Operasional Pendidikan, Madrasah Aliyah, Output Pendidikan

\section{PENDAHULUAN}

Madrasah Aliyah merupakan satuan pendidikan formal dalam binaan Kementrian Agama yang menyelenggarakan pendidikan umum dengan kekhasan agama islam pada jenjang pendidikan menengah. Kegiatan pendidikan yang dijalankan oleh sekolah termasuk juga Madrasah Aliyah harus berdasarkan pada tujuan pendidikan yang ingin dicapai. Pencapaian tujuan pendidikan salah satunya dapat dilihat dari hasil belajar atau output pendidikan, yang di mana output pendidikan ini selalu berkaitan dengan biaya pendidikan.

Biaya operasional pendidikan merupakan hal yang penting dalam penyelenggaraan pendidikan. Dapat dikatakan bahwa proses pendidikan tidak dapat berjalan tanpa dukungan biaya. Biaya pendidikan merupakan salah satu komponen masukan instrumental (instrumental input) yang sangat penting dalam penyelenggaraan pendidikan (di sekolah).

Dalam setiap upaya pencapaian tujuan pendidikan, baik tujuan-tujuan yang bersifat kuantitatif maupun kualitatif biaya pendidikan memiliki peranan yang sangat menentukan. Biaya dalam pendidikan meliputi biaya langsung (direct cost) dan tidak langsung (indirect cost), biaya langsung terdiri dari biaya-biaya yang dikeluarkan untuk keperluan pelaksanaan pengajaran dan kegiatan-kegiatan belajar siswa berupa pembelian alat-alat pembelajaran, sarana belajar, biaya transportasi, gaji guru, baik yang dikeluarkan oleh pemerintah, orang 
tua maupun siswa sendiri. Sedangkan biaya tidak langsung berupa keuntungan yang hilang dalam bentuk biaya yang dikorbankan oleh siswa selama belajar.

Output pendidikan merupakan kinerja sekolah. Sedangkan kinerja sekolah itu sendiri adalah prestasi sekolah yang dihasilkan dari proses atau perilaku sekolah. Kinerja sekolah dapat diukur dari kualitasnya, efektivitasnya, produktivitasnya, efisiensinya, inovasinya, kualitas kehidupan kerjanya, dan moral kerjanya. Output sekolah dapat dikatakan berkualitas dan bermutu tinggi apabila prestasi pencapaian siswa menunjukkan pencapaian yang tinggi dalam bidang:

1. Prestasi akademik, berupa nilai ujian semester, ujian nasional, karya ilmiah, dan lomba akademik.

2. Prestasi non akademik, berupa kualitas iman dan takwa, kejujuran, kesopanan, olahraga, kesenian, keterampilan, dan kegiatan-kegiatan ekstrakulikuler lainnya.

Menurut Supriadi (2009) menyatakan bahwa biaya pendidikan merupakan salah satu komponen masukan (input) yang sangat penting dalam penyelenggaraan pendidikan. Biaya pendidikan diperlukan untuk memfasilitasi pelaksanaan dan program sekolah (intra dan ekstra), dan dapat mengembangkan sekolah sebagai lembaga pendidikan yang memiliki output pendidikan yang berkualitas. ${ }^{1} \mathrm{Hal}$ tersebut sesuai dengan hasil penelitian yang dilakukan oleh Sanjiwani (2012), bahwa biaya pendidikan memiliki korelasi yang signifikan dengan kualitas proses pembelajaran dan aspirasi pendidikan.

Penelitian yang dilakukan oleh Syamsudin, mengatakan bahwa ada dua faktor utama yang dominan terhadap hasil belajar siswa/output siswa yaitu karakteristik siswa yang meliputi (kemampuan, minat, hasil belajar sebelumnya, motivasi) dan karakter pengajaran yang meliputi (guru dan fasilitas belajar). Dalam mewujudkan hal tersebut tentunya membutuhkan biaya yang harus dikeluarkan oleh sekolah atau dikatakan sebagai biaya operasional sekolah/biaya operasional pendidikan. ${ }^{2} \mathrm{Hal}$ tersebut sesuai dengan hasil penelitian yang dilakukan oleh Ekasari (2013) yang menyebutkan bahwa pengaruh biaya pendidikan dan kinerja guru terhadap prestasi belajar SMA Negeri di kabupaten

\footnotetext{
${ }^{1}$ Supriadi. 2009. Satuan Biaya Pendidikan (Dasar dan Menengab).Bandung: Rosda.

2 Syamsudin. 2009. Pengaruh Biaya Pendidikan Terbadap Mutu hasil Belajar Melalui Mutu Proses Belajar Mengajar Pada Sekolah Menengah Pertama Di Kabupaten Asaban. (Tesis Magister Pendidikan e-library).Universitas Sumatera Utara Medan. Medan.
} 
Purwokerto masing-masing memiliki rata-rata sedang, artinya bahwa biaya pendidikan memiliki pengaruh terhadap prestasi belajar.

Pemerintah pusat maupun daerah terus meningkatkan anggaran pendidikan untuk meningkatkan kualitas pendidikan. Hal tersebut sesuai dengan undang-undang Republik Indonesia nomor 20 tahun 2003 pasal 49 ayat (1) tentang Sistem Pendidikan Nasional bahwasanya dana pendidikan selain gaji pendidik dan biaya pendidikan kedinasan dialokasikan minimal 20\% dari Anggaran Pendapatan dan Belanja Negara (APBN) pada sektor pendidikan dan minimal 20\% dari Anggaran Pendapatan dan Belanja Daerah $(\mathrm{APBD}){ }^{3}$

Flower (1998) dalam penelitiannya menjelaskan bahwa orang tua mahasiswa berani mengeluarkan biaya pendidikan yang tinggi bukan untuk memperoleh kualitas pendidikan yang rendah, akan tetapi mereka menginginkan kualitas pendidikan yang tinggi. Kualitas pendidikan yang tinggi bermula dari para pengajar yang memiliki kualifikasi sesuai dengan pelajaran yang mereka ampuh, sedangkan untuk mewujudkan hal tersebut tentunya membutuhkan biaya yang tinggi. ${ }^{4}$

Meskipun penelitian yang dilakukan oleh Elberts dkk. (1999) di Amerika Serikat menyatakan bahwa membayar jasa tidak berpengaruh pada indeks prestasi rata-rata, berkurangnya persentase siswa yang putus kuliah, berkurangnya rata-rata kehadiran setiap hari, dan meningkatnya persentase siswa yang gagal. Akan tetapi penggunaan biaya pendidikan yang efektif dan efisien dapat mempermudah jalannya kegiatan pembelajaran di sekolah terutama mendukung guru dalam melaksankan kegiatan belajar mengajar. Dengan demikian diharapkan mampu meningkatkan output siswa. Kualitas pembelajaran yang baik akan berpengaruh terhadap kualitas hasil belajar (output). ${ }^{5}$

Berdasarkan pemikiran tersebut di atas, indikator output pendidikan dalam penelitian ini dapat dilihat dari hasil NEM ujian nasional (UN). Ujian nasional atau disingkat UN/UNAS adalah sistem evaluasi standar pendidikan dasar dan menengah secara nasional dan persamaan mutu tingkat pendidikan antar daerah yang dilakukan oleh pusat penilaian

\footnotetext{
${ }^{3}$ Undang-undang Republik Indonesia Nomor 20 tahun 2003 tentang Sistem Pendidikan Nasional. Jakarta: CV Ekajaya.

${ }^{4}$ Flower, Ruth. 1998. Cost and quality of higher education The Education Digest; Oct 1998; 64, 2; ProQuest Education Journals pg. 23

${ }^{5}$ Elberts, Randall. at. al. Teacher Performance incentives and Student Outcomes. National Academy of Sciences Conference entitled Devising Incentives to Promote Human Capital, held December 17-18, 1999, in Irvine, California.
} 
pendidikan. Depdiknas di Indonesia berdasarkan Undang-Undang Republik Indonesia no. 20 tahun 2003 menyatakan bahwa dalam rangka pengendalian mutu pendidikan secara nasional dilakukan evaluasi sebagai bentuk akuntabilitas penyelenggara pendidikan kepada pihak-pihak yang berkepentingan. Peraturan Pemerintah (PP) pasal 3 No. 1 tahun 2005 menyebutkan bahwa tujuan diselenggarakannya Ujian Nasional (UN) adalah untuk mengukur dan menilai kompetensi ilmu pengetahuan dan teknologi peserta didik.

Mallet dkk. (2009) menjelaskan bahwa, untuk memaksimalkan output siswa yaitu dengan mengoptimalkan guru sebagai input dalam satuan pendidikan (sekolah). Output siswa yang maksimal dapat tercapai apabila; 1) guru memiliki waktu yang cukup untuk bekerja sama dengan teman sejawat sehingga dapat saling bertukar pikiran dan mengeluarkan ide-ide baru. 2) guru mampu menggunakan waktu dengan efektif. 3) guru memaksimalkan waktunya untuk mencari inovasi baru dalam pembelajaran, sehingga siswa memiliki kesempatan untuk mengembangkan ide-ide mereka sendiri. 4) guru memiliki hasil pengamatan dari teman sejawat, Empat hal yang mempengaruhi maksimalnya output siswa tersebut adalah bagian dari produktivitas kerja guru, sedangkan produktivitas kerja guru yang tinggi diharapkan akan meningkatkan mutu output pendidikan. ${ }^{6}$

Penelitian tentang produktivitas guru pernah dilakukan oleh Jackson, dkk (2010). Jackson, dkk menjelaskan bahwa produktivitas kerja guru sangat dipengaruhi oleh gaji guru dan peningkatan produktivitas guru berakibat pada peningkatan prestasi belajar siswa. sedangkan gaji guru adalah bagian dari unsur biaya operasional pendidikan. Secara umum yang dimaksud dengan produktivitas kerja adalah perbandingan antara hasil yang dicapai (output) dengan keseluruhan sumber daya yang digunakan (input). ${ }^{7}$

Menurut Sutikno (2009) pengukuran produktivitas pendidikan dapat dilakukan dengan tiga cara: (1) dimensi keluaran administrasi, (2) dimensi keluaran perubahan perilaku, (3) dimensi keluaran ekonomi. Pengukuran dari dimensi keluaran administrasi maksudnya adalah dengan melihat seberapa baik pelayanan yang dapat diberikan oleh guru, kepala sekolah maupun pihak lain yang berkepentingan. Adapun dimensi keluaran yang kedua menurut Sutikno (2009) yaitu dimensi perubahan perilaku. Pada dimensi keluaran perubahan perilaku,

\footnotetext{
${ }^{6}$ Mallet, Susanne; Wren, Steve; Dawes, Mark; Blinco, Amy; Haines, Brett; et al. 2009. Optimising Teacher Input - Maximising Output. Mathematics Teaching. (Nov 2009): 38-40.

${ }^{7}$ Jackson, Raegen T; Murnane, Richard J; Willett, John B. 2008. Do worker absences affect productivity? The case of teachers. International Labour Review; 2008; 147, 1; ProQuest Education Journals. pg. 71
} 
produktivitas guru dapat dilihat dari nilai-nilai yang diperoleh peserta didik sebagai gambaran dari prestasi akademik yang telah dicapai. Hasil ujian nasional merupakan salah satu prestasi akademik yang diperoleh peserta didik sebagai efek dari produktivitas guru sebagaimana dalam undang-undang no. 20 tahun 2003, semakin banyak siswa yang lolos ujian nasional, maka semakin banyak output pendidikan yang dihasilkan oleh sekolah tersebut. Sedangkan pengukuran produktivitas yang ketiga menurut Sutikno (2009) yaitu dilihat dari dimensi keluaran ekonomi. Pengukuran dari dimensi keluaran ekonomis dilakukan dengan mengaitkan layanan pendidikan dengan aspek pembiayaan. Dari uraian tersebut di atas, dapat dikatakan bahwa dengan biaya yang maksimal diharapkan mampu menghasilkan output pendidikan yang maksimal pula. ${ }^{8}$

Tujuan penelitian ini adalah untuk mengetahui peran biaya operasional pendidikan terhadap output pendidikan di Madrasah Aliyah yang berada di kota Cimahi. Penelitian ini menggunakan metode studi deskriptif, karena permasalahan yang diteliti merupakan suatu yang aktual dan faktual sehingga peneliti mampu mempelajari secara intensif tentang latar belakang keadaan sekarang. Dalam penelitian ini penulis menggunakan beberapa teknik pengumpulan data yaitu observasi, wawancara dan studi dokumentasi.

\section{METODE}

Penulis menggunakan metode deskriptif, melalui pendekatan kualitatif. Disebut demikian karena sesuai dengan tujuan penelitiannya yaitu melukiskan secara sistematis dan cermat. Oleh karena itu tidak mencari atau menjelaskan hubungan, tidak pula menguji hipotesis atau membuat prediksi, melainkan lebih menitikberatkan pada observasi dan suasana alamiah. ${ }^{9} \quad$ Selanjutnya dalam proses keberlangsungannya peneliti terlibat langsung melakukan observasi penelitian di Madrasah Aliyah Multiteknik Asih Putera dan Madarasah Aliyah Al-Farisy. 1) Observasi, teknik ini ditempuh penulis dengan cara melakukan pengamatan dan pencatatan terhadap permasalahan yang secara langsung penulis lihat dari situasi dan kondisi Madrasah Aliyah Multiteknik Asih Putera dan Madarasah Aliyah AlFarisy. 2) Wawancara, melalui kegiatan wawancara ini peneliti sebagai pewawancara memancing pembicara dari Staff Madrasah Aliyah Multiteknik Asih Putera dan Madarasah

\footnotetext{
8 Sutikno, Atmadji, Tri. 2009. Indikator Produktivitas Kerja Guru Sekolah Menengah Kejuruan. Teknologi dan Kejuruan, Vol. 32, NO. 1, Februari 2009 : 107-118.

${ }^{9}$ Sugiyono. 2008. Metode Penelitian Kuantitatif dan Kualitatif. Bandung: Alfabeta
} 
Aliyah Al-Farisy dan pihak-pihak yang terkait dengan kebutuhan penelitian. Pada prosesnya peneliti berupaya menggiring pembicaraan secara sistematis guna mengetahui segala hal yang berhubungan dengan rumusan masalah penelitian. 3) Dokumentasi, data ini diperoleh melalui pengumpulan dokumentasi dari obyek yang diteliti dengan masalah yang ada. Pada teknisnya penulis meminta bantuan kepada pihak Madrasah Aliyah Multiteknik Asih Putera dan Madarasah Aliyah Al-Farisy untuk memberikan data dokumentasi yang dibutuhkan dalam penelitian ini. Data yang dimaksud berupa arsip-arsip manajerial terkait biaya operasional pendidikan dan output pendidikan di Madrasah Aliyah Multiteknik Asih Putera dan Madarasah Aliyah Al-Farisy.

Proses penelitian ini dilaksanakan secara terus menerus sejak awal penelitian hingga akhir, sehingga melahirkan induktif permasalahan yang diteliti dan kemudian proses pencarian atau penyesuaian pola, model, tema, sampai pada teori yang dirumuskan secara keseluruhan. Seleksi data yang telah terkumpul diklasifikasikan berdasarkan kategori tertentu yang menunjang masalah penelitian, mencari hubungan antara data yang sudah diklasifikasikan dengan teori ideal tentang peran biaya operasional pendidikan terhadap output pendidikan. Kemudian menafsirkan data yang telah dihubungkan antara masalah dengan teori yang ada, dan pada akhirnya penarikan kesimpulan yang didasarkan pada hasil analisis.

\section{HASIL DAN PEMBAHASAN}

Indikator biaya operasional pendidikan dalam penelitian ini sesuai dengan undangundang Republik Indonesia nomor 20 tahun 2003 pasal 49 ayat (1) tentang Sistem Pendidikan Nasional dan peraturan Daerah kota Cimahi (Perda Cimahi) No. 179 tahun 2014 tentang Sistem Penyelenggaraan Pendidikan. Menurut peraturan daerah Kota Cimahi (Perda Cimahi) No. 179 tahun 2014 tentang Sistem Penyelenggaraan Pendidikan menyebutkan bahwa pembiayaan pendidikan meliputi: biaya investasi, biaya operasional, dan biaya personal. Dalam pasal tersebut dijelaskan bahwa biaya operasional pendidikan meliputi: gaji pokok pendidik dan tenaga kependidikan dan tunjangan yang melekat pada gaji, bahan atau peralatan pendidikan habis pakai, dan biaya operasional pendidikan tak langsung berupa daya listrik, telepon, pemeliharaan sarana dan prasarana, uang lembur, transportasi, konsumsi, pajak, dan asuransi. 
Peraturan Mendiknas nomor 69 tahun 2009 juga menjelaskan bahwa, standar biaya operasional non personalia adalah standar biaya yang diperlukan untuk membiayai kegiatan operasi non personalia selama 1 (satu) tahun sebagai bagian dari keseluruhan dana pendidikan agar satuan pendidikan dapat melakukan kegiatan pendidikan secara teratur dan berkelanjutan sesuai Standar Nasional Pendidikan. Biaya operasional non personalia meliputi biaya alat tulis sekolah (ATS), biaya bahan dan alat habis pakai (BAHP), biaya pemeliharaan dan perbaikan ringan, biaya daya dan jasa, biaya transportasi/perjalanan dinas, biaya konsumsi, biaya asuransi, biaya pembinaan siswa/ekstrakurikuler, biaya uji kompetensi, biaya praktik kerja industri (untuk SMK), dan biaya pelaporan. Setiap sekolah memiliki besaran yang berbeda terhadap biaya-biaya tersebut di atas, hal itu sesuai dengan pencapaian tujuan pendidikan yang ditentukan oleh pelaksana sekolah untuk mewujudkan output pendidikan yang berkualitas.

Biaya operasional pendidikan yang dikeluarkan oleh pemerintah dikelola secara mandiri oleh sekolah masing-masing. Sekolah swasta memiliki kebijakan masing-masing dalam menentukan biaya operasional masing-masing sekolahnya. Upaya pemerintah maupun swasta yang terus meningkatkan biaya operasional pendidikan setiap tahunnya dimaksudkan untuk membantu sekolah dalam meningkatkan output pendidikan di setiap tahunnya.

Penelitian ini fokus pada madrasah aliyah yang sudah meluluskan 1 tahun terakhir, sehingga data yang diambil adalah pada tahun pelajaran 2016-2017. Hasil observasi menyebutkan bahwa ada 8 Madrasah Aliyah di Cimahi baik swasta maupun negeri yang sudah meluluskan siswa siswinya. Tenaga pendidik atau guru MA baik negeri maupun swasta di kota Cimahi, berdasarkan data dari kementrian agama kota Cimahi pada tahun pelajaran 2016-2017 berjumlah 207 PTK sedangkan pada tahun pelajaran 2017-2018 adalah sebanyak 209 guru. Jumlah guru mengalami kenaikan rata-rata sebesar 5\%, sedangkan jumlah siswa Madrasah Aliyah tahun 2016-2017 yakni 1129 siswa dengan jumlah lulusan pada tahun ajaran 2016-2017 sebanyak 363dan jumlah siswa pada tahun pelajaran 2017-2018 adalah sebanyak 1302 siswa. Jumlah siswa Madrasah Aliyah di kota Cimahi mengalami kenaikan rata-rata sebesar 7,5\% setiap tahunnya. Hal tersebut menunjukkan bahwa kenaikan jumlah siswa di setiap tahunnya lebih besar dari pada jumlah guru. Kenaikan jumlah siswa dan guru mengakibatkan naiknya biaya operasional pendidikan yang seharusnya dapat mengakibatkan kenaikan output pendidikan juga. 
Tabel 1. Data lembaga, jumlah siswa, jumlah lulusan dan jumlah guru.

Madrasah Aliyah di Kota Cimahi Tahun Ajaran 2016-2017

\begin{tabular}{|c|c|c|c|c|c|}
\hline NO & Nama Lembaga & Alamat & Siswa & Lulusan & PTK \\
\hline 1. & $\begin{array}{l}\text { MA Multiteknik Asih } \\
\text { Putera }\end{array}$ & $\begin{array}{l}\text { Jl. Daeng Muhammad } \\
\text { Ardiwinata No. } 199 \\
\text { Cimahi. }\end{array}$ & 153 & 52 & 21 \\
\hline 2. & MA Miftahussaadah & $\begin{array}{l}\text { Jl. Raya Cibabat Blk. } 400 \\
\text { No. } 43 \text { Cibabat, Kota } \\
\text { Cimahi }\end{array}$ & 57 & 30 & 21 \\
\hline 3. & MA Nurul Iman & $\begin{array}{l}\text { Jl. Cipageran Blk. No. } 160 \\
\text { Cimahi Utara Kota } \\
\text { Cimahi }\end{array}$ & 103 & 16 & 24 \\
\hline 4. & MAN Cimahi & $\begin{array}{l}\text { Jl. Kihapit Barat No. } 139 \\
\text { leuwigajah, kecamatan } \\
\text { cimahi selatan, kota } \\
\text { cimahi. }\end{array}$ & 562 & 178 & 58 \\
\hline 5. & MA Al-Musdariyah & $\begin{array}{l}\text { Jl. Kamarung No.110 } \\
\text { Kota Cimahi }\end{array}$ & 49 & 21 & 13 \\
\hline 6. & MA Nurul Falah & $\begin{array}{l}\text { Jl. Mahar Martanegara no. } \\
130 \text { kota Cimahi }\end{array}$ & 84 & 23 & 22 \\
\hline 7. & MA As-Sa'adah & $\begin{array}{l}\text { Jl. Sadarmanah no. } 110 \\
\text { kota Cimahi }\end{array}$ & 44 & 22 & 16 \\
\hline 8. & MA Al-Farisy & $\begin{array}{l}\text { Jl. Kp. Babut Girang } \\
\text { 03/11 Cibabat, } \\
\text { Kecamatan Cimahi Utara, } \\
\text { kota Cimahi. }\end{array}$ & 48 & 21 & 13 \\
\hline & Jumlah & & 1129 & 363 & 207 \\
\hline
\end{tabular}

Pada penelitian ini ada 2 sekolah yang menjadi objek sampel untuk dijadikan penelitian sehingga mengetahui peran biaya operasional pendidikan terhadap output pendidikan yakni Madrasah Aliyah Mutiteknik Asih Putera dan Madrasah Aliyah Al-Farisy. Output pendidikan pada penelitian ini dilihat dari nilai rata-rata NEM Ujian Negara siswa dari setiap sekolahnya.

Jumlah siswa Madrasah Aliyah Multiteknik Asih Putera pada tahun ajaran 20162017 sebanyak 153 orang dan pada tahun ajaran 2017-2018 sebanyak 143 orang, sedangkan jumlah siswa Madrasah Aliyah Al-Farisy pada tahun ajaran 2016-2017 sebanyak 48orang dan pada tahun ajaran 2017-2018 sebanyak 41 orang. Hal tersebut sudah bisa menjelaskan bahwa secara kuantitas Madrasah Aliyah Multiteknik Asih Putera lebih unggul dan baik dibanding dengan Madrasah Aliyah Al-Farisy. 
Di bawah ini ada total biaya operasional yang dikeluarkan 2 sekolah yang menjadi objek sampel dalam penelitian ini, yang diambil pada tahun ajaran 2016- 2017, yakni sebagai berikut :

Tabel 2. Total biaya operasional Pendidikan Tahun Ajaran 2016-2017

\begin{tabular}{|l|l|l|}
\hline No & \multicolumn{1}{|c|}{ Nama Sekolah } & \multicolumn{1}{c|}{ BOP } \\
\hline 1. & Madrasah Aliyah Multiteknik Asih Putera & Rp. 184.200.000 \\
\hline 2. & Madrasah Aliyah Al-Farisy & Rp. 84.200 .000 \\
\hline
\end{tabular}

Tabel di atas menunjukkan bahwa biaya operasional pendidikan Madrasah Aliyah Multiteknik Asih Putera lebih besar dibanding dengan biaya operasional pendidikan Madrasah Aliyah Al-Farisy yang mencapai perbedaannya pun sampai dengan Rp. 1.00.000.000, perbedaan ini semua sudah jelas disebabkan karena kuantitas dan kualitas yang ada di sekolah tersebut berbeda.

Selanjutnya berhubung output pendidikan dalam penelitian ini adalah rata-rata nilai ujian nasional (NEM) oleh karena itu di sini dijelaskan terlebih dahulu kondisi mutu output pendidikan Madrasah Aliyah di kota Cimahi yang antara lain dapat dilihat dari rata-rata NEM Ujian Nasional dari seluruh Madrasah Aliyah yang diperoleh pada tahun pelajaran 2016/2017. Rata-rata NEM Ujian Nasional mengalami fluktuatif selama 1 tahun terakhir. Kondisi umum mutu output pendidikan madrasah aliyah di kota Cimahi dapat dilihat dari tabel rata-rata NEM UN madrasah aliyah di kota Cimahi sebagai berikut:

Tabel 3. Rata-Rata Nilai Ujian Nasional MA di kota Cimahi (Output Pendidikan). Tahun Ajaran 2016-2017

\begin{tabular}{|l|l|l|}
\hline No & \multicolumn{1}{|c|}{ Nama Sekolah } & \multicolumn{1}{|c|}{$\begin{array}{c}\text { Rata-Rata } \\
\text { NEM }\end{array}$} \\
\hline 1. & MA Multiteknik, Asib Putera & 57.11 \\
\hline 2. & MA Miftahussaadah & 51.51 \\
\hline 3. & MA Nurul Iman & 51.46 \\
\hline 4. & MAN Cimahi & 45.55 \\
\hline 5. & MA Al-Musdariyah & 45.43 \\
\hline 6. & MA Nurul Falah & 43.39 \\
\hline 7. & MA As-Sa'adah & 39.21 \\
\hline 8. & MA Al-Farisy & 35.85 \\
\hline & Rata-Rata NEM MA di kota Cimahi & 46.18 \\
\hline & Rata-Rata NEM MA Tertinggi & 57.11 \\
\hline & Rata-Rata NEM MA Terendah & 35.85 \\
& & \\
\hline
\end{tabular}


Tabel di atas menunjukkan bahwa, output pendidikan Madrasah Aliyah di kota Cimahi pada tahun ajaran 2016-2017 tergolong baik. Hal itu dikarenakan, secara keseluruhan nilai-nilai tersebut berada di atas nilai minimal yang telah distandarkan oleh pemerintah sebagai nilai standar minimum kelulusan. Tabel tersebut menunjukkan bahwa Madrasah Aliyah di kota cimahi mampu menghasilkan output pendidikan yang baik, yaitu dengan nilai rata-rata 46.18, dengan Output pendidikan tertinggi diperoleh Madrasah Aliyah Multiteknik Asih Putera yaitu dengan nilai rata-rata 57.11 dan output pendidikan terendah adalah Madrasah Aliyah Al-Farisy yaitu dengan nilai rata-rata 35.85.

Hal ini bermakna bahwa, besarnya biaya operasional pendidikan yang dikeluarkan oleh Madrasah Aliyah di Kota Cimahi rata-rata mengakibatkan output pendidikan yang dalam hal ini nilai NEM UN siswa, semakin meningkat pula. Akan tetapi ada juga sekolah yang mengeluarkan biaya operasional pendidikannya kecil di banding sekolah lain tapi besar pada hasil NEM ujian nasionalnya.

Berdasarkan landasan data penelitian yang sudah dijelaskan, yang di mana di sini hanya difokuskan pada dua sekolah yakni Madrasah Aliyah Multiteknik Asih Putera dan Madrasah Aliyah Al-Farisy, bahwasanya terdapat peran dari biaya operasional pendidikan sehingga mempengaruhi ouput pendidikan yakni artinya bahwa pembiayaan pendidikan memberikan kontribusi yang signifikan terhadap peningkatan mutu (output) pendidikan. Meskipun demikian ada beberapa hal yang kemungkinan dapat menyebabkan tidak berpengaruhnya biaya operasional pendidikan terhadap output pendidikan.

Hal ini sejalan dengan yang diungkapkan oleh Fattah (1999), hasil penelitian tersebut menjelaskan bahwa pembiayaan pendidikan memberikan kontribusi yang positif terhadap peningkatan mutu (output) pendidikan. Biaya operasional pendidikan dalam penelitian ini berpengaruh terhadap output pendidikan. Hal tersebut disebabkan antara lain karena semua indikator biaya operasional pendidikan digunakan secara langsung dan baik dalam rangka peningkatan output pendidikan (peningkatan nilai NEM siswa). Penggunaan biaya operasional tersebut benar-benar digunakan berdasarkan standar nasional pendidikan (PP no.19 tahun 2005). ${ }^{10}$

Alghrim juga mengungkapkan dalam tulisannya bahwa biaya pendidikan menjadi issue utama dalam meningkatkan prestasi siswa (output), dan menjadikan produktivitas

10 Fattah, Nanang. 1999. Analisis Hubungan Pembiayaan Pendidikan Sekolah Dasar dengan Mutu Proses dan Hasil Belajar. Mimbar Pendidikan. FIP IKIP Bandung. No. 3/XVIII/1999. 
sebagai sesuatu yang penting untuk menghubungkan antara biaya pendidikan dengan prestasi siswa (output siswa). Alghrim mengungkapkan bahwa produktivitas guru berpengaruh terhadap kualitas hasil belajar siswa, di mana produktivitas guru dilihat dari tingkat kehadirannya di sekolah. Kehadiran guru di sekolah tidak menjamin guru tersebut berkomunikasi langsung atau berinteraksi langsung dengan siswa. bekerjasama untuk saling mengeluarkan ide dan gagasan yang dimiliki oleh keduanya. Jumlah guru yang banyak juga tidak menjamin dapat meningkatkan kualitas pendidikan (output pendidikan), jika kualitas tersebut tidak diimbangi dengan kuantitas yang bagus pula (cost). Intinya keberadaan guru untuk menghasilkan lulusan yang berkualitas harus dilihat dari kuantitas sekolahnya, perlu ada peningkatan kompetensi dari guru tersebut yang menjadi tanggung jawab sekolah, sehingga memerlukan anggaran yang khusus untuk mewujudkan hal tersebut, dengan demikian akan berdampak pada peningkatan output pendidikan. ${ }^{11}$

Penelitian ini sedikit kurang sejalan dengan yang diungkapkan oleh Elberts dkk. (1999) di Amerika Serikat yang menyatakan bahwa membayar jasa dalam hal ini adalah termasuk dari biaya operasional pendidikan, tidak berpengaruh terhadap indeks prestasi rata-rata (output pendidikan), berkurangnya persentase siswa yang putus sekolah, berkurangnya rata-rata kehadiran setiap hari, meningkatnya persentase siswa yang gagal atau tidak lulus. Siswa yang tidak lulus disini adalah siswa yang memiliki nilai hasil studi yang rendah.

Penelitian lain yang kurang sejalan juga diungkapkan oleh Flower (1998) di Amerika Serikat yang mengungkapkan bahwa tingginya biaya yang dikeluarkan oleh mahasiswa, tidak berdampak pada kualitas pendidikan yang tinggi pula dari mahasiswa tersebut, kualitas pendidikan di sini adalah nilai hasil studi yang diperoleh mahasiswa. Hasil penelitiannya juga mengungkapkan bahwa biaya yang dikeluarkan oleh mahasiswa tidak digunakan secara efektif dan efisien oleh pihak lembaga pendidikan dalam hal peningkatan kompetensi guru/dosen pengajar, dimana guru/pengajar adalah unsur yang terlibat langsung dalam pembelajaran bersama siswa/mahasiswa.

Komisi nasional bidang pendidikan di Amerika Serikat juga mengungkapkan tentang biaya pendidikan yang ditulis oleh Fitzpatrick (2006), bahwa perguruan tinggi bidang akademi keperawatan di Amerika Serikat telah melakukan perombakan sistem

11 Ahlgrim, W Richard. 2010. A Through and Efficient Education: School Funding, Student Achivement and Productuvity. (Unpublished doctoral dissertation). Indiana State University. Terre Haute, Indiana 
pendidikan yaitu dengan menurunkan biaya pendidikan, dikarenakan selama ini biaya pendidikan mahasiswa di akademi tersebut sangat tinggi, akan tetapi tidak memberikan dampak terhadap meningkatnya kualitas (output) dari pendidikan itu sendiri. ${ }^{12}$

\section{KESIMPULAN}

Data terkait tema ini diambil dari 2 sekolah yang ada di kota Cimahi yakni Madprasah Aliyah Multiteknik Asih Putera dan Madrasah Aliyah Al-Farisy yang di mana peran biaya operasional pendidikan pada penelitian ini memberikan pengaruh terhadap output pendidikan. Artinya biaya operasional pendidikan yang tinggi rata-rata mengakibatkan hasil output pendidikan lebih baik. Hal ini sejalan dengan beberapa penelitian terdahulu seperti yang diungkapkan oleh Fattah (1999), hasil penelitian tersebut menjelaskan bahwa pembiayaan pendidikan memberikan kontribusi yang positif terhadap peningkatan mutu (output) pendidikan. Biaya operasional pendidikan dalam penelitian ini berpengaruh terhadap output pendidikan. Hal tersebut disebabkan antara lain karena semua indikator biaya operasional pendidikan digunakan secara langsung dan baik dalam rangka peningkatan output pendidikan (peningkatan nilai NEM siswa). Penggunaan biaya operasional tersebut benar-benar digunakan berdasarkan standar nasional pendidikan (PP no.19 tahun 2005).

\section{DAFTAR PUTAKA}

Ahlgrim, W Richard. 2010. A Through and Efficient Education: School Funding, Student Achivement and Productuvity. (Unpublished doctoral dissertation). Indiana State University. Terre Haute, Indiana

Elberts, Randall. at. al. Teacher Performance incentives and Student Outcomes. National Academy of Sciences Conference entitled Devising Incentives to Promote Human Capital, held December 17-18, 1999, in Irvine, California.

Fattah, Nanang. 1999. Analisis Hubungan Pembiayaan Pendidikan Sekolah Dasar dengan Mutu Proses dan Hasil Belajar. Mimbar Pendidikan. FIP IKIP Bandung. No. 3/XVIII/1999.

Fitzpatrick, Joyce J. 2006. The Cost and Quality Agenda Comes to Higher Education. Nursing Education Perspectives; Nov/Dec 2006; 27, 6; ProQuest Education Journals. $\operatorname{Pg} 297$.

\footnotetext{
12 Fitzpatrick, Joyce J. 2006. The Cost and Quality Agenda Comes to Higher Education. Nursing Education Perspectives; Nov/Dec 2006; 27, 6; ProQuest Education Journals. Pg 297.
} 
Flower, Ruth. 1998. Cost and quality of higher education The Education Digest; Oct 1998; 64, 2; ProQuest Education Journals pg. 23

Jackson, Raegen T; Murnane, Richard J; Willett, John B. 2008. Do worker absences affect productivity? The case of teachers. International Labour Review; 2008; 147, 1; ProQuest Education Journals. pg. 71

Mallet, Susanne; Wren, Steve; Dawes, Mark; Blinco, Amy; Haines, Brett; et al. 2009. Optimising Teacher Input - Maximising Output. Mathematics Teaching. (Nov 2009): $38-40$.

Sugiyono. 2008. Metode Penelitian Kuantitatif dan Kualitatif. Bandung: Alfabeta

Sutikno, Atmadji, Tri. 2009. Indikator Produktivitas Kerja Guru Sekolah Menengah Kejuruan. Teknologi dan Kejuruan, Vol. 32, NO. 1, Februari 2009 : 107-118.

Supriadi, Dedi. 2004. Satuan Biaya Pendidikan (Dasar dan Menengah).Bandung: Rosda.

Syamsudin. 2009. Pengaruh Biaya Pendidikan Terhadap Mutu hasil Belajar Melalui Mutu Proses Belajar Mengajar Pada Sekolah Menengah Pertama Di Kabupaten Asahan. (Tesis Magister Pendidikan e-library).Universitas Sumatera Utara Medan. Medan

Undang-undang Republik Indonesia Nomor 20 tahun 2003 tentang Sistem Pendidikan Nasional. Jakarta: CV Ekajaya. 